ceeded in collecting a quantity of the adult thrips which were submitted to Dr. W. E. Hinds of Auburn, Alabama, who pronounced them to be Euthrips tritici (Fitch), whose habit of working in strawberries is well known.

Since finding the blemished fruit in our western fruit belt, the writer has observed similarly blemished fruit in various stores in other parts of the state where peaches were offered for sale.

R. H. Petrit, Entomologist of Experiment Station, Michigan Agricultural College, East Lansing, Michigan.

\title{
THIRTY-FIRST ANNUAL MEETING, AMERICAN ASSOCIATION OF ECONOMIC ENTOMOLOGISTS
}

\author{
Baltimore, Md.-December 30-31, 1918
}

The Thirty-first Annual Meeting of this Association will be held in Baltimore, Md, December 30 and 31,1918 . Owing to war conditions it has been thought best to arrange a program which will give particular prominence to the insect problems that are vital ir connection with war activities.

Members are requested to forward titles of the papers which they wish to present, and to submit subjects which are of special importance in connection with winning the war. New discoveries or information which has recently been secured along these lines should be presented for consideration at the meeting.

In order that the program can be completed, so that it can be printed in the December issue of the JodrnaL, it is necessary that all titles of papers be in the hands of the secretary not later than November 9, 1918.

Applications for membership may be secured from the secretary, or from the chairman of the committee on membership. It is especially desired that all applications be filled out, endorsed and placed in the hands of the chairman of that committee well in advance of the date of the meeting.

A. F. BuRgess, Secretary.

\section{MEMBERSHIP COMMITTEE NOTICE}

Precedent provides that active members desiring to nominate associate members for active membership shall file such nominations with the chairman of the membership committee prior to the annual meeting. Nominations must be accompanied by full information concerning the nominee's publications and other qualifications. Where possible, copies of the publications enumerated should accompany the application.

It is also earnestly requested that associate members send a list of their publications, or better the publications themselves, together with a list of papers by other authors with which they have been associated during the investigation, to the chairman of the membership committee, marking them "For membership committee" so that they may be available to the committee in considering promotions from associate to active membership. Copies of publications should be sent to each member of the committee when possible. 